

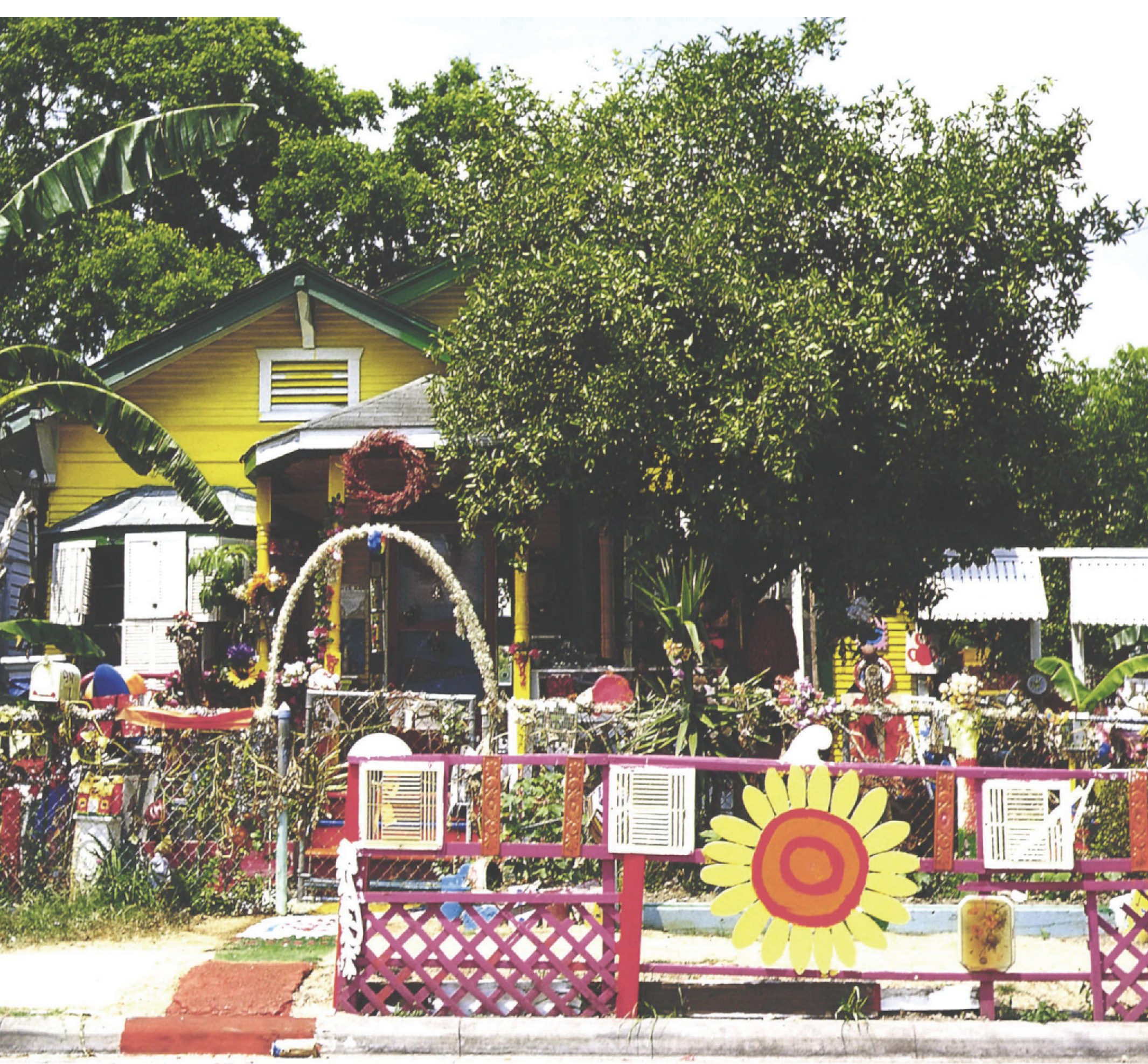


Yard Art and Handmade Places

EXTRAORDINARY EXPRESSIONS OF HOME

Jill Nokes, with Pat Jasper

Foreword by Betty Sue Flowers

Principal photography by Krista Whitson 
Copyright $(C) 2007$ by Jill Nokes and Krista Whitson. All photos by Krista Whitson unless otherwise noted.

\section{Printed in China}

Second printing, 2008

All rights reserved

Requests for permission to reproduce material from this work should be sent to:

Permissions

University of Texas Press

P.O. Box 7819

Austin, TX 78713-7819

www.utexas.edu/utpress/about/bpermission.html

Book and jacket design by Lisa Tremaine

ISBN 978-0-292-73531-6 (library e-book)

ISBN 978-0-292-78799-5 (individual e-book)
Library of Congress Cataloging-in-Publication Data

\section{Nokes, Jill, 195I-}

Yard art and handmade places : extraordinary expressions of home / Jill Nokes, with Pat Jasper ; foreword by Betty Sue Flowers; Krista Whitson, principal photographer. — Ist ed. p. $\mathrm{cm}$.

Includes index.

ISBN 978-0-292-71679-7 (cloth : alk. paper)

I. Garden ornaments and furniture-Texas. 2. Decorative arts-Texas. 3. Gardens-Texas-Design. I. Jasper, Pat. II. Title.

\section{SB473.5.N65 2007}

$712.609764-\mathrm{dc22}$

2007011574 
Dedicated to my dear Jack, with love and gratitude 
This page intentionally left blank. 